\title{
Streptomyces plumbiresistens sp. nov., a lead- resistant actinomycete isolated from lead-polluted soil in north-west China
}

\author{
Jun Kang Guo,† Yan Bing Lin,† Mei Ling Zhao, Ran Sun, Ting Ting Wang, \\ Ming Tang and Ge Hong Wei
}

Correspondence

Ge Hong Wei

weigehong@yahoo.com.cn

\author{
College of Life Sciences, Shaanxi Key Laboratory of Molecular Biology for Agriculture, Northwest A \\ \& F University, Yangling Shaanxi 712100, PR China
}

Pollution of soils with heavy metals is becoming one of the most severe environmental hazards. Elevated levels of heavy metals not only decrease soil microbial activity and crop production, but also threaten human health through the food chain (McLaughlin et al., 1999). Selection pressure in polluted habitats has led to adaptation, resulting in microorganisms possessing special resistance mechanisms as a consequence of their permanent exposure to heavy metals. Increasing numbers of environmental micro-organisms have been studied as part of investigations into methods to remediate heavy metal contamination (Thompson \& Watling, 1987; Smith et al., 1994). Some micro-organisms, e.g. members of the genera Citrobacter and Pseudomonas, both Gram-negative, rod-shaped bacteria growing in heavy metal-contaminated sites, have been found with the ability to resist and accumulate the heavy metal lead (Aickin \& Dean, 1979; Macaskie \& Dean, 1987). There have been previous reports on the effects of heavy metals (except for

†These authors contributed equally to this work.

The GenBank/EMBL/DDBJ accession number for the 16S rRNA gene sequence of strain CCNWHX 13-160' is EU526954.

The growth and culture characteristics of strain CCNWHX $13-160^{\top}$ on different media (Table S1), the fatty acid composition of strain CCNWHX 13-160 (Table S2), growth characteristics of strain CCNWHX $13-160^{\top}$ and related strains in the presence of various lead concentrations (Table S3) and a graph showing the effects of lead concentration on survival of strain CCNWHX 13-160' (Fig. S1) are available with the online version of this paper. lead) on a range of Streptomyces species (Abbas \& Edwards, 1989). Since actinomycetes are susceptible to heavy metals (Lugauskas et al., 2005), little is known about their presence in soils contaminated with heavy metals, especially lead.

The novel strain, CCNWHX $13-160^{\mathrm{T}}$, was isolated by the dilution plating method from a sample of lead-polluted soil collected from Huixian ( $33^{\circ} 54^{\prime} 10.3^{\prime \prime} \mathrm{N} 106^{\circ} 07^{\prime} 44.3^{\prime \prime} \mathrm{E}$; altitude of $1049 \mathrm{~m}$ ), Gansu province, north-west China, in July 2006. The medium used was modified Gause's synthetic agar $(16.0 \mathrm{~g}$ soluble starch, $4.0 \mathrm{~g}$ D-glucose; $1.0 \mathrm{~g}$ potassium nitrate, $0.5 \mathrm{~g}$ potassium phosphate dibasic trihydrate, $0.5 \mathrm{~g}$ magnesium sulfate heptahydrate, $0.001 \mathrm{~g}$ ferrous sulfate heptahydrate, $0.5 \mathrm{~g}$ sodium chloride, $20 \mathrm{~g}$ agar powder, $0.5 \mathrm{mg}$ vitamin B compound and $1000 \mathrm{ml}$ distilled water; $\mathrm{pH}$ 7.2). The isolate was maintained on modified Gause's synthetic agar slopes and as glycerol suspensions $(20 \%, \mathrm{v} / \mathrm{v})$ at $-20{ }^{\circ} \mathrm{C}$. Biomass for most of the chemotaxonomic and molecular systematic studies was harvested after incubation in shake flasks of modified Gause's broth at $28{ }^{\circ} \mathrm{C}$ for $4-7$ days.

Morphological properties were examined by light microscopy (CX31; Olympus) and scanning electron microscopy (6360LV; JSM) after cultivation for 2 weeks on modified Gause's synthetic agar medium at $28{ }^{\circ} \mathrm{C}$. Colours were determined using the methods described by Kelly (1964).

Analysis of the diaminopimelic acid isomers and whole-cell sugars in whole-cell hydrolysates was performed according 
to Lechevalier \& Lechevalier (1980). Fatty acids were extracted as described by Kämpfer \& Kroppenstedt (1996) and estimated by GC using the standard Sherlock MIDI (Microbial Identification) system. Menaquinones were examined by the method of Collins (1985) and phospholipids were determined following the procedure of Lechevalier et al. (1981).

Strain CCNWHX $13-160^{\mathrm{T}}$ was examined for a range of chemotaxonomic and physiological properties following the methods of Williams et al. (1983). International Streptomyces Project (ISP) media were used to determine the colours of diffusible pigments and the utilization of sole carbon and nitrogen sources (Shirling \& Gottlieb, 1966). Temperature and $\mathrm{pH}$ tolerances were determined on Bennett's agar plates after incubation for 2 weeks. Resistance to antibiotics was carried out according to $\mathrm{Al}$ Tai et al. (1999).

Genomic DNA extraction and 16S rRNA gene PCR amplification were carried out according to Chun \& Goodfellow (1995). The universal bacterial 16S rRNA gene primers [forward primer P1 (5'-CGGGATCCAGAGTTTGATCCTGGCTCAGAACGAACGCT- $3^{\prime}$ ) and reverse primer P6 (5'-CGGGATCCTACGGCTACCTTGTTACGACTTCACCCC- $\left.3^{\prime}\right)$ ] were used. The PCR product was purified and sequenced directly by an automated DNA sequencing system (ABI 3730XL). The 16S rRNA gene sequence of the strain was aligned manually by CLUSTAL_X version 1.8 (Thompson et al., 1997) with the almost complete 16S rRNA gene sequences of type strains of recognized species of the genus Streptomyces obtained from GenBank/EMBL/ DDBJ. A phylogenetic tree was constructed using the neighbour-joining (Saitou \& Nei, 1987), minimum-evolution (Rzhetsky \& Nei, 1993) and maximum-parsimony (Fitch, 1971) methods in the TREECON software package version 1.3b (Van de Peer \& De Wachter, 1994) and the MEGA3.1 software package (Kumar et al., 2004). The genetic distance matrices were estimated by the Kimura twoparameter model (Kimura, 1980). The topology of the tree was evaluated in a bootstrap analysis based on 1000 replicates (Felsenstein, 1985). The DNA G + C content was determined using the thermal melting protocol (Marmur \& Doty, 1962) with Escherichia coli K-12 as the standard. DNA-DNA relatedness was determined by the initial renaturation rate method in triplicate (De Ley et al., 1970).

The methods of Amoroso et al. (1998) were used to determine the lead resistance of strain CCNWHX 13-160 ${ }^{\mathrm{T}}$. Spore suspensions $\left(1 \times 10^{9}\right.$ c.f.u. $\left.\mathrm{ml}^{-1}\right)$ of the strain were prepared as described by Kieser et al. (2000). Samples of liquid medium $(16.0 \mathrm{~g}$ soluble starch, $4.0 \mathrm{~g}$ D-glucose, $1.0 \mathrm{~g}$ potassium nitrate, $0.5 \mathrm{~g}$ potassium phosphate dibasic trihydrate, $0.5 \mathrm{~g}$ magnesium sulfate heptahydrate and $1000 \mathrm{ml}$ distilled water; $\mathrm{pH}$ 6.0) containing different concentrations of $\mathrm{Pb}\left(\mathrm{NO}_{3}\right)_{2} \quad(0.5-5.0 \mathrm{mM})$ and each inoculated with $100 \mu \mathrm{l}$ spore suspension were incubated with shaking (150 r.p.m.) at $28{ }^{\circ} \mathrm{C}$ for 4 days. After being centrifuged $(5000 \mathrm{~g}, 10 \mathrm{~min})$, the cell pellets were washed three times with $25 \mathrm{mM}$ Tris-EDTA buffer ( $\mathrm{pH}$ 8.0). To analyse the weight changes of the culture, the pellets were dried to constant weight at $105{ }^{\circ} \mathrm{C}$. Residual lead in the supernatants was determined by atomic absorption spectrophotometry (180-80; Hitachi). All samples were analysed in triplicate and mean values were determined.

The chemotaxonomic and morphological properties of strain CCNWHX $13-160^{\mathrm{T}}$ were consistent with those of members of the genus Streptomyces (Williams et al., 1989). The strain formed a highly branched substrate mycelium and aerial hyphae which differentiated into Rectiflexibiles spore chains with smooth, greenish white spores (Fig. 1). The growth of the organism was moderate on ISP3, ISP4, ISP5 and ISP6 agars, but poor on nutrient agar. The colour of the aerial hyphal mass was white to greyish white and the substrate mycelium was light yellow to brownish red on ISP6, Bennett's agar and ISP3. A brown diffusible pigment was produced on ISP4, ISP5, Bennett's agar and Gause's synthetic agar (Table 1 and Supplementary Table S1, available in IJSEM Online).

The whole cell hydrolysates contained LL-diaminopimelic acid, but no diagnostic sugars (cell wall type I) (Lechevalier \& Lechevalier, 1980). The major menaquinones of the novel strain were hexahydrogenated, octahydrogenated and tetrahydrogenated with nine isoprene units [MK-9(H6, H8 and H4)]. The major polar lipids were phosphatidylethanolamine, phosphatidylinositol and phosphatidylinositol mannosides (phospholipid type II) (Lechevalier et al., 1981). Analysis of the major fatty acid components showed that the organism contained mainly iso- and anteisobranched-chain fatty acids and a small proportion of unsaturated fatty acids (Supplementary Table S2, available in IJSEM Online).

The almost complete 16S rRNA gene sequence (1429 nt) of strain CCNWHX $13-160^{\mathrm{T}}$ was aligned with $16 \mathrm{~S}$ rRNA gene sequences of other Streptomyces species and a distinct phyletic line was formed with Streptomyces pseudovenezuelae NBRC $12904^{\mathrm{T}}$. The strain was closely related to $S$.

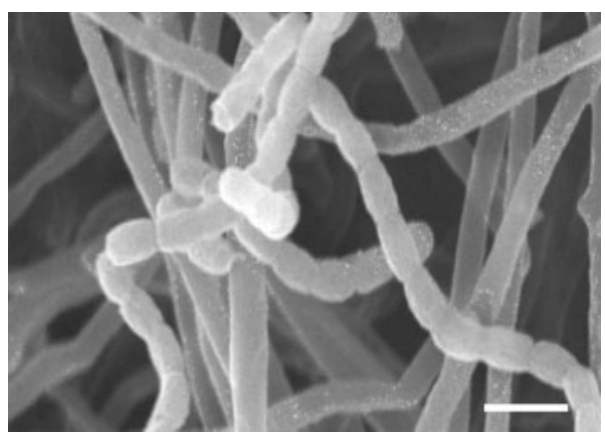

Fig. 1. Scanning electron micrograph of the Rectiflexibiles spore chains and smooth-surfaced spores of strain CCNWHX 13-160 ${ }^{\top}$ after cultivation for 2 weeks at $28{ }^{\circ} \mathrm{C}$ on modified Gause's synthetic agar medium. Bar, $2 \mu \mathrm{m}$. 


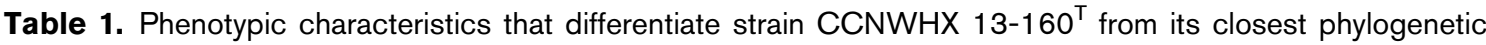
relatives, S. pseudovenezuelae NBRC $12904^{\top}$ and S. resistomycificus NBRC $12814^{\top}$

Strains: 1, CCNWHX 13-160 ${ }^{\mathrm{T}}$; 2, S. pseudovenezuelae NBRC $12904^{\mathrm{T}}$; 3, S. resistomycificus NBRC $12814^{\mathrm{T}}$. Data for reference type strains are taken from Fujie et al. (1993) and Omura et al. (1978). All strains are positive for utilization of L-arabinose, D-fructose, glucose, myo-inositol, D-mannitol, D-mannose, raffinose, L-rhamnose and sucrose. +, Positive; -, negative; $(+)$, weakly positive.

\begin{tabular}{|c|c|c|c|}
\hline Characteristic & 1 & 2 & 3 \\
\hline Aerial spore mass colour & Greenish white & Pale, yellowish & Grey \\
\hline Spore chain morphology & Rectiflexibiles & Rectiflexibiles & Spiral, Rectiflexibiles \\
\hline Production of diffusible pigments & Brown & None & Brown, reddish brown \\
\hline Melanin production & - & - & + \\
\hline \multicolumn{4}{|c|}{ Utilization as sole carbon source $(1.0 \%, \mathrm{w} / \mathrm{v})$ : } \\
\hline Glycerin & + & - & - \\
\hline D-Ribose & - & - & + \\
\hline Trehalose & - & - & + \\
\hline D-Xylose & + & $(+)$ & - \\
\hline \multicolumn{4}{|c|}{ Utilization as sole nitrogen source $(1.0 \%, \mathrm{w} / \mathrm{v})$ : } \\
\hline L-Phenylalanine & - & + & + \\
\hline L-Tyrosine & - & + & - \\
\hline \multicolumn{4}{|l|}{ Degradation of: } \\
\hline Cellulose & - & + & - \\
\hline Xanthine & + & + & - \\
\hline \multicolumn{4}{|l|}{ Growth at/in: } \\
\hline $45^{\circ} \mathrm{C}$ & + & + & - \\
\hline $\mathrm{NaCl}(8 \%)$ & - & + & - \\
\hline pH 12 & + & + & $(+)$ \\
\hline $\mathrm{H}_{2} \mathrm{~S}$ production & + & + & - \\
\hline Gelatin liquefaction & - & - & + \\
\hline Milk coagulation & + & - & + \\
\hline Milk peptonization & + & - & + \\
\hline Nitrate reduction & + & - & + \\
\hline
\end{tabular}

pseudovenezuelae NBRC $12904^{\mathrm{T}}$ and Streptomyces resistomycificus NBRC $12814^{\mathrm{T}}$ with sequence similarities of 98.9 and $98.8 \%$, respectively (Fig. 2).

DNA-DNA relatedness studies were carried out between strain CCNWHX $13-160^{\mathrm{T}}$ and the most closely related type strains (S. pseudovenezuelae NBRC $12904^{\mathrm{T}}$ and S. resistomycificus NBRC $12814^{\mathrm{T}}$ ); DNA-DNA relatedness values were $49.7 \pm 0.8$ and $43.2 \pm 1.1 \%$, respectively, and both values were significantly lower than the $70 \%$ cut-off point recommended for the delineation of genomic species (Wayne et al., 1987).

It is clear that strain CCNWHX $13-160^{\mathrm{T}}$ differs from its most closely related phylogenetic neighbours S. pseudovenezuelae NBRC $12904^{\mathrm{T}}$ and S. resistomycificus NBRC $12814^{\mathrm{T}}$ (Table 1). Physiological characteristics, degradation of organic compounds and production of diffusible pigments enabled strain CCNWHX $13-160^{\mathrm{T}}$ to be distinguished from closely related type strains.

Strain CCNWHX13-160 ${ }^{\mathrm{T}}$ grew well in liquid medium supplemented with $0.5 \mathrm{mM} \mathrm{Pb}^{2+}$ and visible growth was observed in the presence of $2.0 \mathrm{mM} \mathrm{Pb}^{2+}$. S. pseudovenezuelae NBRC $12904^{\mathrm{T}}$ and S. resistomycificus NBRC $12814^{\mathrm{T}}$ could not grow in the presence of $2.0 \mathrm{mM} \mathrm{Pb}^{2+}$ (see
Supplementary Table S3, available in IJSEM Online). The MIC of $\mathrm{Pb}^{2+}$ for strain CCNWHX $13-160^{\mathrm{T}}$ was $4.0 \mathrm{mM}$. The MIC was determined by the intersection of the relative survival curve with the horizontal axis. The relative survival curve was produced using weight changes of cultures that were supplemented with different concentrations of lead compared with non-lead-supplemented controls under the same conditions (see Supplementary Fig. S1, available in IJSEM Online). Several strains of the genus Frankia are known to be resistant to $\mathrm{Pb}^{2+}$ (MIC 5-8 mM) (Richards et al., 2002). However, Escherichia coli W3110 (MIC $2.0 \mathrm{mM}$ ), Bacillus subtilis 168 (MIC $3.0 \mathrm{mM}$ ) and Micromonospora echinospora ATCC $15836^{\mathrm{T}}$ (MIC $3.0 \mathrm{mM}$ ) are less resistant to lead (Richards et al., 2002).

Based on a combination of phenotypic and genotypic studies, strain CCNWHX $13-160^{\mathrm{T}}$ represents a novel species of the genus Streptomyces, for which the name Streptomyces plumbiresistens sp. nov. is proposed.

\section{Description of Streptomyces plumbiresistens sp. nov.}

Streptomyces plumbiresistens (plum.bi.re.sis'tens. L. n. plumbum lead; L. part adj. resistens resisting; N.L. part 


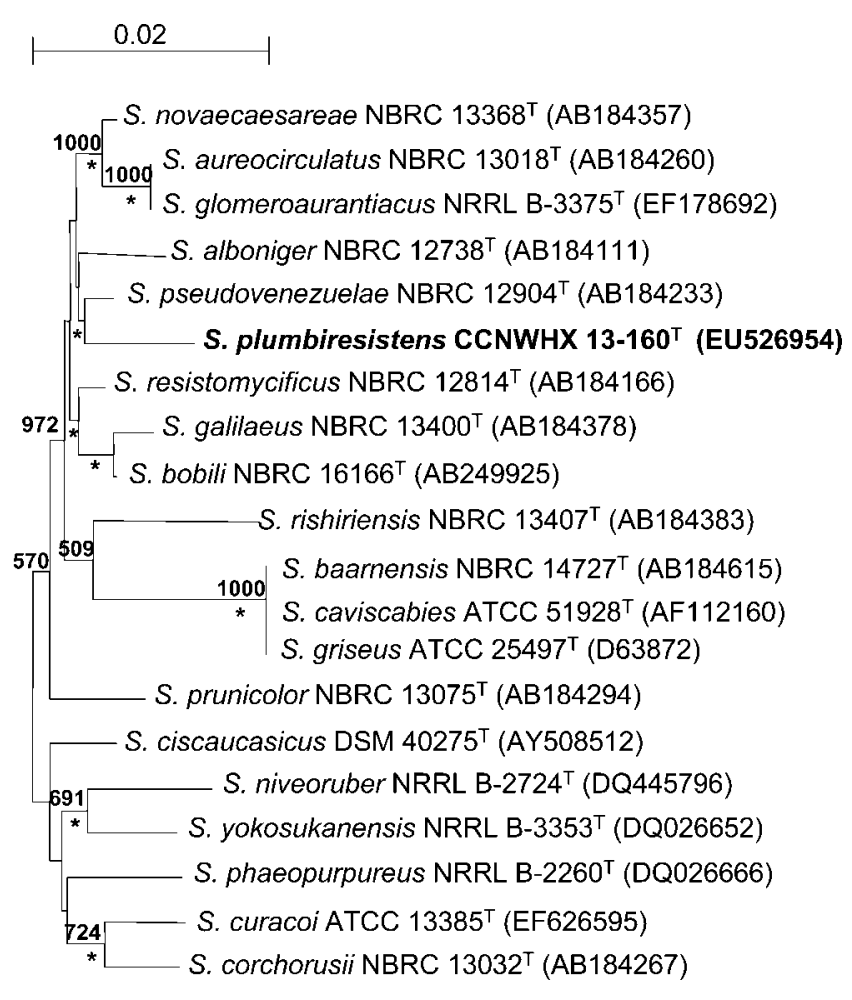

Fig. 2. Neighbour-joining tree based on almost complete $16 \mathrm{~S}$ rRNA gene sequences (1429 nt) showing relationships between strain CCNWHX $13-160^{\top}$ and related type strains of the genus Streptomyces. Asterisks indicate branches that were also found using the minimum-evolution and maximum-parsimony tree-making algorithms. Numbers at branching nodes indicate bootstrap values (based on 1000 replications). Bar, 0.02 substitutions per nucleotide position.

adj. plumbiresistens lead-resisting, referring to the organism's ability to resist lead).

Aerobic, Gram-positive, lead-resistant actinomycete that forms a well-branched white to greyish white aerial mycelium and light yellow to brownish red substrate mycelium on ISP6, Bennett's agar and ISP3. Produces Rectiflexibiles spore chains with smooth, greenish white spores. A brown diffusible pigment is produced on ISP4, ISP5, Bennett's agar and Gause's synthetic agar. Melanin production is negative on ISP6 and ISP7. Growth occurs at $10-45{ }^{\circ} \mathrm{C}, \mathrm{pH} 5.0-12.0$ and in the presence of $5-7 \%(\mathrm{w} / \mathrm{v}) \mathrm{NaCl}$, but not at 0 or $50{ }^{\circ} \mathrm{C}, \mathrm{pH} 4.0$ or 13.0 , or in $8 \%(\mathrm{w} / \mathrm{v}) \mathrm{NaCl}$. Milk coagulation and peptonization, nitrate reduction and $\mathrm{H}_{2} \mathrm{~S}$ production are positive. Gelatin liquefaction and degradation of cellulose are negative. L-Arabinose, D-fructose, galactose, glucose, glycerin, myo-inositol, lactose, maltose, mannose, raffinose, rhamnose, starch, sucrose and D-xylose are utilized as sole carbon sources, but not ribose or trehalose. The peptidoglycan contains LL-diaminopimelic acid (cell wall type I). The predominant menaquinones are MK-9(H6, H8 and $\mathrm{H} 4)$. The major fatty acids are iso- $\mathrm{C}_{14: 0}, \mathrm{C}_{14: 0}$, iso- $\mathrm{C}_{15: 0}$, anteiso- $\mathrm{C}_{15: 0}, \mathrm{C}_{15: 0}$, iso- $\mathrm{C}_{16: 0}, \mathrm{C}_{16: 0}$ and anteiso- $\mathrm{C}_{17: 0}$.
The type strain, CCNWHX $13-160^{\mathrm{T}}\left(=\mathrm{ACCC} 41207^{\mathrm{T}}=\right.$ HAMBI $2991^{\mathrm{T}}$ ), was isolated from a lead-contaminated soil sample collected from Gansu Province, north-west China. The genomic DNA $\mathrm{G}+\mathrm{C}$ content of the type strain is $70.9 \mathrm{~mol} \%$.

\section{Acknowledgements}

This work was supported by projects from the National Science Foundation of China (30670372, 30630054), National Program for Basic S \& T Platform Construction (2005DKA21201) and PCSIRT (IRT0748). We are grateful to Dr Kristina Lindstrom and Professor Jiang Ruibo for deposition of the strain in the culture collections.

\section{References}

Abbas, A. \& Edwards, C. (1989). Effects of metals on a range of Streptomyces species. Appl Environ Microbiol 55, 2030-2035.

Aickin, R. M. \& Dean, A. C. R. (1979). Lead accumulation by Pseudomonas fluorescens and by a Citrobacter sp. Microbios Lett 9, 55-66.

Al-Tai, A., Kim, B., Kim, S. B., Manfio, G. P. \& Goodfellow, M. (1999). Streptomyces malaysiensis sp. nov., a new streptomycete species with rugose, ornamented spores. Int J Syst Bacteriol 49, 1395-1402.

Amoroso, M. J., Castro, G. R., Carlino, F. J., Romero, N. C., Hill, R. T. \& Oliver, G. (1998). Screening of heavy metal-tolerant actinomycetes isolated from the Salí River. J Gen Appl Microbiol 44, 129-132.

Chun, J. \& Goodfellow, M. (1995). A phylogenetic analysis of the genus Nocardia with $16 \mathrm{~S}$ rRNA gene sequences. Int J Syst Bacteriol 45, 240-245.

Collins, M. D. (1985). Isoprenoid quinone analysis in classification and identification. In Chemical Methods in Bacterial Systematics, pp. 267-287. Edited by M. Goodfellow \& D. E. Minnikin. London: Academic Press.

De Ley, J., Cattoir, H. \& Reynaerts, A. (1970). The quantitative measurement of DNA hybridization from renaturation rates. Eur $J$ Biochem 12, 133-142.

Felsenstein, J. (1985). Confidence limits on phylogenies: an approach using the bootstrap. Evolution 39, 783-791.

Fitch, W. M. (1971). Toward defining the course of evolution: minimum change for a specific tree topology. Syst Zool 20, 406-416.

Fujie, K., Shinguh, Y., Hatanaka, H., Shigematsu, N., Murai, H., Fujita, T., Yamashita, M., Okamoto, M. \& Okuhara, M. (1993). FR901277, a novel inhibitor of human leukocyte elastase from Streptomyces resistomycificus. Producing organism, fermentation, isolation, physico-chemical and biological properties. J Antibiot (Tokyo) 46, 908-913.

Kämpfer, P. \& Kroppenstedt, R. M. (1996). Numerical analysis of fatty acid patterns of coryneform bacteria and related taxa. Can J Microbiol 42, 989-1005.

Kelly, K. L. (1964). Inter-Society Color Council - National Bureau of Standards Color Name Charts Illustrated with Centroid Colors. Washington, DC: US Government Printing Office.

Kieser, T., Bibb, M. J., Buttner, M. J., Chater, K. F. \& Hopwood, D. A. (2000). Practical Streptomyces Genetics. Norwich: The John Innes Foundation.

Kimura, M. (1980). A simple method for estimating evolutionary rates of base substitutions through comparative studies of nucleotide sequences. J Mol Evol 16, 111-120. 
Kumar, S., Tamura, K. \& Nei, M. (2004). MEGA3: integrated software for Molecular Evolutionary Genetics Analysis and sequence alignment. Brief Bioinform 5, 150-163.

Lechevalier, H. A. \& Lechevalier, M. P. (1980). The chemotaxonomy of actinomycetes. In Actinomycete Taxonomy (Special Publication 6), pp. 277-284. Edited by A. Dietz \& D. W. Thayer. Arlington, VA: Society of Industrial Biology.

Lechevalier, M. P., Stern, A. E. \& Lechevalier, H. A. (1981). Phospholipids in the taxonomy of actinomycetes. Zentralbl Bakteriol Hyg Abt 1 Suppl 11, 111-116.

Lugauskas, A., Levinskaitë, L., Peèiulytë, D., Repeèkienë, J., Motuzas, A., Vaisvalavièius, R. \& Prosyèevas, I. (2005). Effect of copper, zinc and lead acetates on microorganisms in soil. Ekologija 1, 61-69.

Macaskie, L. E. \& Dean, A. C. R. (1987). Use of immobilized biofilm of Citrobacter sp. for the removal of uranium and lead from aqueous flows. Enzyme Microb Technol 9, 2-4.

Marmur, J. \& Doty, P. (1962). Determination of the base composition of deoxyribonucleic acid from its thermal denaturation temperature. $J$ Mol Biol 5, 109-118.

McLaughlin, M. J., Parker, D. R. \& Clarke, J. M. (1999). Metals and micronutrients - food safety issues. Field Crops Res 60, 143-163.

Omura, S., Tanaka, H., Iwai, Y., Nishigaki, K., Awaya, J., Takahashi, Y. \& Masuma, R. (1978). A new antibiotic, setomimycin, produced by a strain of Streptomyces. J Antibiot (Tokyo) 31, 1091-1098.

Richards, J. W., Krumholz, G. D., Chval, M. S. \& Tisa, L. S. (2002). Heavy metal resistance of Frankia strains. Appl Environ Microbiol 68, 923-927.

Rzhetsky, A. \& Nei, M. (1993). Theoretical foundation of the minimum-evolution method of phylogenetic inference. Mol Biol Evol 10, 1073-1095.
Saitou, N. \& Nei, M. (1987). The neighbor-joining method: a new method for reconstructing phylogenetic trees. Mol Biol Evol 4, 406-425.

Shirling, E. B. \& Gottlieb, D. (1966). Methods for characterization of Streptomyces species. Int J Syst Bacteriol 16, 313-340.

Smith, L. A., Alleman, B. C. \& Copley-Graves, L. (1994). Biological treatment options. In Emerging Technology for Bioremediation of Metals, pp. 1-12. Edited by J. L. Means \& R. E. Hinchee. New York: Lewis Publishers.

Thompson, G. A. \& Watling, R. J. (1987). Bioaccumulation potential of heterotrophic bacteria for lead, selenium, and arsenic. Bull Environ Contam Toxicol 38, 1049-1054.

Thompson, J. D., Gibson, T. J., Plewniak, F., Jeanmougin, F. \& Higgins, D. G. (1997). The CLUSTAL_X windows interface: flexible strategies for multiple sequence alignment aided by quality analysis tools. Nucleic Acids Res 25, 4876-4882.

Van de Peer, Y. \& De Wachter, R. (1994). TREECON for Windows: a software package for the construction and drawing of evolutionary trees for the Microsoft Windows environment. Comput Appl Biosci 10, 569-570.

Wayne, L. G., Brenner, D. J., Colwell, R. R., Grimont, P. A. D., Kandler, O., Krichevsky, M. I., Moore, L. H., Moore, W. E. C., Murray, R. G. E. \& other authors (1987). International Committee on Systematic Bacteriology. Report of the ad hoc committee on reconciliation of approaches to bacterial systematics. Int J Syst Bacteriol 37, 463-464.

Williams, S. T., Goodfellow, M., Alderson, G., Wellington, E. M. H., Sneath, P. H. A. \& Sackin, M. J. (1983). Numerical classification of Streptomyces and related genera. J Gen Microbiol 129, 1743-1813.

Williams, S. T., Goodfellow, M. \& Alderson, G. (1989). Genus Streptomyces Waksman and Henrici 1943, 339 ${ }^{\mathrm{AL}}$. In Bergey's Manual of Systematic Bacteriology, vol. 4, pp. 2452-2492. Edited by S. T. Williams, M. E. Sharpe \& J. G. Holt. Baltimore: Williams \& Wilkins. 